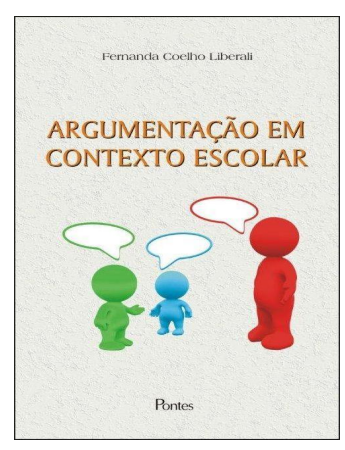

LIBERALI, Fernanda Coelho. Argumentação em contexto escolar. Campinas: Pontes, 2013.

\title{
Argumentação Colaborativa nas Múltiplas Realidades dos Contextos Escolares
}

\author{
Clara Regina Rodrigues de Souza* \\ Maria Cristina Caldas de Camargo Lima Damianovic**
}

Argumentaģão em contexto escolar é uma obra seminal para todo educador que, de fato, esteja preocupado em proporcionar um ensino-aprendizado inclusivo por meio da linguagem organizada com base na argumentação colaborativa. Significa realmente usar na escola, em suas diferentes esferas, a argumentação como uma metodologia de organização e análise discursiva, que construa significados compartilhados a partir de diversas possibilidades de representar e viver a realidade que se vive. Inclusivo significa ensinar-aprender com a compreensão de que existem verdades sobre o dia a dia fora da escola que precisam ser trazidas para discussão.

Essa discussão é iluminada pela possibilidade da argumentação colaborativa, proposta por Liberali, de criar formas para entender as realidades de modo que os seres humanos possam ir além das verdades únicas comumente impostas pela escola. O estudo criterioso da pesquisadora

\footnotetext{
* Mestre em Linguagem e Ensino da Universidade Federal de Campina Grande-PB (2014). Doutoranda em Linguística pelo Programa de Pós-Graduação em Letras (PPGL) da Universidade Federal de Pernambuco (UFPE).Contato: clararegina.r.s@gmail.com. ** Doutorado em Linguística Aplicada e Estudos da Linguagem pela Pontífica Universidade Católica de São Paulo. Professora Adjunta III da Universidade Federal de Pernambuco (UFPE). Contato: mcdamianovic@gmail.com.
} 
sobre categorias de produção e análise da argumentação possibilita que o ensino-aprendizagem forje indivíduos que aprendem a fazer e respeitar escolhas para seu futuro e o do próximo de maneira mais informada.

Em sua obra inspiradora, a autora explica que ser mais informado está relacionado ao engajamento pela busca de posicionamentos, evidências, explicações, exemplificações, correlações entre posições que possibilitem saber fazer e respeitar escolhas. Este processo com base na argumentação colaborativa minimiza questões de exclusão e aumenta as situações de inclusão na escola, as quais são sublinhadas no estudo norteador de Liberali, à medida que a autora integra os aspectos enunciativo-discursivo-linguísticos na potencialização da produção criativa de um significado compartilhado.

Liberali compartilha sua preocupação, de mais de uma década, em estudar alternativas para a criação intensa de novas escolhas e ideias múltiplas no contexto escolar. São 124 páginas de grande carga informacional, organizadas em quatro capítulos: 1. Estudos sobre argumentação e suas implicações para contextos escolares: uma visão panorâmica; 2. Estudos sobre argumentação em trabalhos de formação de educadores em contextos escolares; 3. Categorias argumentativas para entender e transformar contextos escolares; 4 . Estudos sobre argumentação em contextos escolares. Estes apresentam e discutem, de maneira objetiva, didática e reflexiva, trabalhos com pressupostos teóricos de base sócio-histórico-cultural sobre a argumentação colaborativa.

Em seu primeiro capítulo, Liberali apresenta discussões sobre argumentação no contexto escolar em dois momentos: i) em Estudos sobre argumentação e suas implicações, traça-se um percurso histórico sobre argumentação que contempla dos estudos retóricos aristotélicos (350 a.C.), perpassa os novos estudos, em 1958, perelmanianos e toulminianos, até as preocupações mais relacionadas com o ensino da linguagem, que entendem a argumentação mobilizada em gêneros textuais; ii) em Estudos sobre argumentação em situações escolares, realiza-se um consistente estado da arte, enfocando a sala de aula e as produções dos alunos.

No segundo, de forma vibrante, são apresentados e discutidos resultados de estudos prático-teóricos que incentivam atividades criativas em que a argumentação esteia processos de produção de significados, por meio do discurso internamente persuasivo em situações para a colaboração entre parceiros. Primeiramente, Vozes na produção de atividades criativas possibilita 
estudo da argumentação através das formas de assimilação dos discursos de outros, motivo pelo qual se considera impositivo o discurso de autoridade de haver apenas um sentido para o significado ser aceito, transmitido e reconhecido. Em seguida, Gestão escolar, formação de educadores e argumentação explicita a proposta de uma argumentação colaborativa que compartilhe ideias, desejos, valores em processo de participação de cada um na produção de significados e considere posicionamentos, perspectivas, distintos modos de ver e agir no mundo, nos espaços escolares.

No terceiro, discutem-se categorias enunciativas, discursivas e linguísticas para a análise argumentativa no contexto escolar, esclarecendo a sua interdependência nos contextos de ação, formação e gestão de educadores. As primeiras categorias enfocam o contexto de realização de determinado evento, na medida em que consideram a dialética entre o local, momento, veículo, participantes, objetivos, conteúdos e modos concretos de produção-realização. As segundas compreendem o plano organizacional, a organização temática, o foco sequencial e a construção do discurso que relacionam o modo como o texto pode ser disposto. As terceiras revelam mecanismos, da materialidade do texto, conversacionais, de coesão verbal e nominal, lexicais, valorativos, de conexão, de distribuição das vozes, modalizadores, interrogativos, de proferição e de trocas de turnos.

No quarto capítulo, são discutidas, de forma motivadora, diversas pesquisas sobre argumentação, sob orientação de Liberali, seja no tocante ao ensino-aprendizagem, seja à formação de educadores e gestão escolar. Os trabalhos apresentados têm em comum o entendimento da argumentação colaborativa como propiciadora à produção de conhecimentos, às relações entre interlocutores e seus novos modos de agir, tanto para a constituição criativa de significados compartilhados por alunos e professores nos estudos sobre a relação entre ensino-aprendizagem e argumentação, bem como para a compreensão da formação crítica e gestão de educadores.

Para além dos capítulos, ganham destaques substanciais o prefácio e o posfácio do liv ro, especialmente pelas apreciações que situam estudiosos iniciantes da argumentação e apontam meios para pesquisadores mais experientes buscarem mais lastros teóricos. No prefácio, Elaine Mateus discute expressivamente a importância da pedagogia da argumentação para professores que se dedicam a práticas democráticas que possibilitem 
criticidade, reflexão e posicionamentos articulados frente a questões sociais políticas, econômicas e culturais. Mateus valoriza a obra de Liberali delineando três importantes aspectos para uma teoria de argumentação: i) debate, com seus conflitos e diferenças de valores e racionalidade para diversos posicionamentos; ii) diálogo, com a distinção entre posições teóricas que denomina de epistêmico-retórica (antropológico-relativista) da pragmáticadialética (crítico-racionalista); iii) discussão, com a exploração de práticas de diálogo e de dinâmicas de grupo em contextos organizacionais. Consequentemente, a formadora de professores situa o livro prefaciado nas perspectivas de base crítica e multicultural, pelo tratamento da argumentação como produção criativa de novas possibilidades, mediante compreensão de diversos pontos de vista, da exploração de significados e ideologias, para que ações éticas, sentimentos e práticas sejam reorientados.

No posfácio, Liberali revaloriza o papel da argumentação colaborativa na construção de significados novos e relevantes para contextos escolares, por: engajar sujeitos em intensa participação afeto-cognitiva na produção coletiva de conhecimentos; compreender a existência de múltiplas formas possíveis de representar a realidade; a escola ser um contexto privilegiado para reflexão sobre a vivência; o formador poder ser instigador de apresentação de pontos de vista, suportes, contraposições e novas posições; o formando poder ter posicionamentos respeitáveis frente aos temas em debate e questionamentos; organizar a interação e criação de multiplicidade de participação; criar possibilidades e tomadas de escolhas/decisões. A própria autora revela o pensamento de educação libertadora da obra, pela desmistificação da crença de respostas certas/erradas em ensino/aprendizagem, em detrimento das contribuições para a produção de um universo de escolhas e de modos de ver, analisar, avaliar.

Liberali, em sua obra de vanguarda, apresenta como a argumentação colaborativa pode potencializar o respeito aos saberes e autonomia dos educandos, a criticidade, a ética, a rejeição a qualquer forma de discriminação, a reflexão e assunção da identidade cultural por meio da consciência do inacabado, da necessidade do bom senso, da humildade, da apreensão da realidade, alegria, esperança, curiosidade, comprometimento e disponibilidade para o diálogo verdadeiro. O livro oferece um excelente estudo para profissionais interessados em superar a educação vertical e assimétrica, de 
forma que alunos e professores escolham sair do aprisionamento de uma carga conteudística imposta e partam para a coconstrução da possibilidade de transformar e produzir conhecimento na escola.

Recebido em: 10/06/2015

Aceito: $17 / 11 / 2015$ 